\title{
Hubungan Kepuasan Pelayanan Makanan dengan Jenis Diet pada Pasien di RSU Haji Surabaya
}

\author{
Relationship of Food Service Satisfaction with Type of Diet in \\ Patients at RSU Haji Surabaya
}

Indy Armareza Lora Pratama*1

\begin{abstract}
ABSTRAK
Latar Belakang: Pelayanan gizi merupakan salah satu upaya penting untuk mendukung preventif, promotif dan rehabilitatif. Pelayanan gizi di rumah sakit dapat mendukung dan mempercepat proses penyembuhan pasien dengan pemberian diet yang sesuai kebutuhan.

Tujuan: Penelitian ini bertujuan untuk menganalisis hubungan kepuasan pelayanan makanan dengan jenis diet pada pasien di RSU Haji Surabaya.

Metode: Penelitian ini merupakan penelitian analitik dengan desain cross sectional. Populasi penelitian terdiri dari 79 pasien rawat Rumah Sakit Umum Haji Surabaya dengan besar sampel 48 pasien. Sampel diambil menggunakan simple random sampling. Penelitian dilakukan dengan wawancara menggunakan kuesioner kepuasan pelayanan makanan. Analisa data menggunakan uji chi-square dengan CI sebesar $95 \%$ $(\alpha=0,05)$.

Hasil: Tingkat kepuasan pelayanan makanan menunjukkan 22 puas (45,8\%) dan 26 tidak puas $(54,2 \%)$. Kepuasan pelayanan makanan berhubungan signifikan dengan jenis diet ( $\mathrm{p}=0,002)$.

Kesimpulan: Kepuasan pelayanan makan pada pasien memiliki hubungan signifikan dengan jenis diet. Rumah sakit harus memperhatikan kepuasan makan pasien dan meningkatkan konseling kepada pasien.
\end{abstract}

Kata kunci: kepuasan pasien, makanan lunak, makanan biasa

\begin{abstract}
Background: Nutrition service is influential to support preventive, promotive and rehabilitative efforts to patients in hospital. Nutrition service could support the recovery of patients more quickly.

Objectives: This study aims to analyze correlation of food service satisfaction and type of diet in patients at RSU Haji Surabaya.

Methods: This study is an analytical study with a cross sectional design. The study population consisted of 79 patients hospitalized in RSU Haji Surabaya with sample size of 48 patients. The sample was taken using simple random sampling. The study was conducted by interview using a food service satisfaction questionnaire. Data analysis using chi-square test with CI of $95 \%(\alpha=0.05)$.

Results: Satisfaction of food service in patients was significant relationship with the type of diet. Hospitals must pay attention to patient satisfaction and improve counseling to patients.

Conclusions: Patient satisfaction of food was significant associate with texture of foods but not significant with gender, age, and occupation. Hospitals must to pay attention to patient satisfaction, especially in soft foods
\end{abstract}

Keywords: patient satisfaction, soft food, regular food

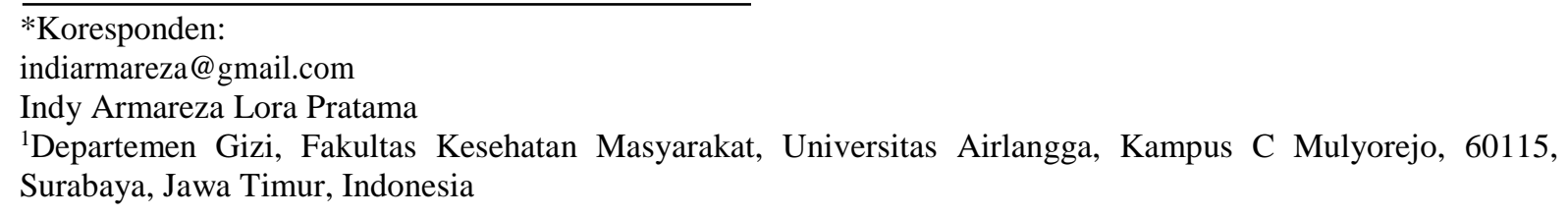




\section{PENDAHULUAN}

Penyelenggaraan makan di rumah sakit terdiri dari kegiatan yang dimulai dari perencanaan menu sampai penyajian makan kepada pasien (Mas'ud, Nur Rochimiwati and Sahariah Rowa, 2015). Pelayanan gizi di rumah sakit terdiri dari empat kegiatan pokok yaitu asuhan gizi pasien rawat jalan, asuhan gizi pasien rawat inap, penyelenggaraan makan, penelitian dan pengembangan gizi terapan (Kementerian Kesehatan RI, 2013). Penyelenggaraan makan di rumah sakit dapat mempercepat proses penyembuhan pasien sehingga diperlukan diit yang sesuai (Daniella Geertruida Maria Rumokoy*, Nova H. Kapantow*, 2016). Jenis makanan berdasarkan standar di rumah sakit meliputi makanan biasa, makanan lunak, makanan lumat/saring dan makanan cair (Almatsier, 2001).

Pelayanan Gizi merupakan salah satu upaya penting untuk mendukung preventif, promotif dan rehabilitative (Marhaeni et al., 2014). Pelayanan gizi di rumah sakit dapat mendukung dan mempercepat proses penyembuhan pasien dengan pemberian diet yang sesuai dengan kebutuhan (Anwar, Herianandita and Ruslita, 2012). Makanan lunak memiliki proses pengolahan yang lebih sulit dibandingkan makanan biasa karena kadar air yang tinggi, tidak digoreng serta menggunakan bumbu yang tidak merangsang sehingga membuat cita rasa makanan lebih hambar (Herlina, 2015). Proses pengolahan ini berbeda dengan makanan biasa sesuai dengan kebiasaan sehari-hari pasien (Herlina, 2015).

Kepuasan pasien dalam penyelenggaraan makanan rumah sakit dapat dinyatakan sebagai ekspektasi dan persepsi pasien terhadap kualitas pelayanan (Hartwell et al., 2006). Kepuasan pasien merupakan komponen penting yang dapat menentukan kualitas pelayanan (Hartwell et al., 2006). Faktor yang mempengaruhi kepuasan pelayanan makan pada pasien terdiri dari faktor internal dan eksternal (Hospitality, 2005). Faktor internal meliputi jenis kelamin, usia, status ekonomi, keadaan psikologis serta kebiasaan makan pasien dirumah sedangkan faktor eksternal terdiri dari cita rasa, sanitasi alat makan, ketepatan waktu penyajian, pelayanan tenaga pramusaji serta lama perawatan (Hospitality, 2005).

Penelitian Anwar di Jakarta menyatakan bahwa pasien yang mendapatkan pelayanan gizi menunjukkan ketidakpuasan, yang terlihat bahwa 40\% responden menyisakan makanannya diatas Standar Kementerian Kesehatan (>20\%) karena porsi yang terlalu banyak, rasa kurang enak, kenyang dan malas untuk makan (Anwar, Herianandita and Ruslita, 2012). Penelitian lain di RSI Jemursari Surabaya oleh Amalia menunjukkan ketidakpuasan pada pasien yang dapat ditunjukkan sebanyak 31,73\% makanan yang tersisa dari menu makan pagi (Habiba and Adriani, 2017). Hasil penelitian Oktaria pada pelayanan gizi di Rumah Sakit Bhayangkara menunjukkan ketidakpuasan, yang dapat ditunjukkan dari banyaknya sisa makanan pasien (>25\%) (Oktaria, 2014). Dari hasil penelitian tersebut dapat disimpulkan bahwa masih dijumpai sisa makanan pasien $>20 \%$ dan belum sesuai standar dari Kementerian Kesehatan dalam Pedoman Pelayanan Gizi di Rumah Sakit sehingga mempengaruhi tingkat kepuasan pada pelayanan makan di rumah sakit (Kementerian Kesehatan RI, 2013).

Berdasarkan hasil studi pendahuluan dengan Ahli Gizi di Rumah Sakit Umum Haji Surabaya, menyatakan bahwa masih terdapat komplain dari pasien terkait dengan makanan yang disajikan, salah satunya yaitu mengenai cita rasa dari makanan. Selain itu, ahli gizi tersebut juga menyatakan bahwa sisa makanan di rumah sakit masih cukup banyak. Sebagian besar pasien menyisakan sayur dan nasi pada menu yang disajikan. Hal tersebut akan mempengaruhi adanya sisa makanan rumah sakit sehingga berdampak pada kepuasan pada pelayanan makan di rumah sakit. Sesuai dengan Kemenkes RI (2013), faktor-faktor yang dapat mempengaruhi kepuasan pasien adalah ketepatan waktu distribusi makanan, variasi menu makanan, cita rasa makanan, kebersihan alat, serta penampilan petugas.

Berdasarkan hasil studi pendahuluan dengan Ahli Gizi di Rumah Sakit Umum Haji Surabaya, dijelaskan bahwa masih terdapat komplain dari pasien terutama terkait dengan cita rasa makanan. Adanya komplain ini berdampak terhadap kepuasan pada pelayanan makan di rumah sakit. Sesuai dengan Peraturan Kemenkes RI, faktor-faktor yang dapat mempengaruhi kepuasan pasien adalah ketepatan waktu distribusi makanan, variasi menu makanan, cita rasa makanan, kebersihan alat, serta penampilan petugas (Kementerian Kesehatan RI, 2013).

Rumah Sakit Umum Haji Surabaya memiliki Standar Pelayanan Minimal Rumah Sakit tersendiri dengan mengacu pada Standar Pelayanan Minimal Rumah Sakit menurut Pedoman Gizi Rumah Sakit Tahun 2013. Standar Pelayanan Minimal Rumah Sakit ini digunakan sebagai acuan untuk mengevaluasi dan memonitoring pelayanan gizi di rumah sakit. Standar Pelayanan Minimal Rumah Sakit Umum Haji Surabaya memiliki empat sasaran mutu yaitu ketepatan waktu distribusi makanan pasien 100\%, ketepatan pemberian diit pasien $100 \%$, sisa makanan pasien kurang dari $20 \%$ dan kepuasan pelayanan pasien $90 \%$.

Penelitian ini bertujuan untuk menganalisis hubungan kepuasan pelayanan makanan dengan jenis diit pada pasien di RSU Haji Surabaya. Penelitian ini diharapkan dapat digunakan sebagai masukan untuk penyelenggaraan makan di rumah sakit sehingga dapat meningkatkan kepuasan pada pelayanan makan pasien. 


\section{METODE}

Penelitian ini merupakan penelitian observasional analitik dengan desain cross sectional. Populasi penelitian ini adalah pasien rawat inap di gedung Shafa dan Marwah Rumah Sakit Umum Haji Surabaya yang berjumlah 79 pasien. Besar sampel yang diambil dalam penelitian sebanyak 48 responden. Teknik pengambilan sampel menggunakan simple random sampling dengan pengambilan secara acak sederhana menggunakan undian. Pemilihan sampel dilakukan dengan menentukan sampel sesuai kriteria inklusi sampel yaitu pasien di gedung Shafa dan Marwah yang bersedia menjadi responden yakni pasien yang telah dirawat $\geq 2$ hari di Ruang Marwah 1, Ruang Marwah 2, Marwah 3, Shafa 3 dan Shafa 4 dan telah mendapatkan pelayanan makanan dari rumah sakit baik makan pagi, siang, maupun sore, pasien dalam keadaan sadar dan mendapat diet secara oral baik makanan biasa maupun lunak tanpa memperhitungkan jenis diet serta pasien yang telah mendapatkan konseling dari ahli gizi. Variabel independen dalam penelitian ini yaitu kualitas makanan, kualitas pelayanan makanan serta jenis makanan. Ukuran kualitas makanan yang diukur meliputi porsi makanan, cita rasa, tekstur makanan dan warna makanan. Sedangkan kualitas pelayanan makanan yang diukur adalah penyajian makanan, kebersihan dan penggunaan alat makan, pembagian makanan, penampilan petugas penyaji serta konsultasi gizi. Sedangkan variabel jenis makanan dibagi menjadi makanan lunak dan makanan biasa. Variabel dependen penelitian ini adalah kepuasan makan pasien. Penelitian ini dilaksanakan pada bulan Agustus 2018 di RSU Haji Surabaya. Penelitian dilakukan dengan wawancara menggunakan kuesioner kepuasan pelayanan makanan yang telah disediakan oleh RSU Haji Surabaya dan telah diuji validitasnya. Kemudian dilakukan scoring menggunakan skala likert dengan 4 kategori yaitu sangat tidak puas, tidak puas, puas dan sangat puas (Sugiyono, 2009). Analisis hubungan kepuasan pelayanan makanan dengan jenis diet dioleh dengan uji chi square dengan tingkat kepercayaan sebesar $95 \%(\alpha=0,05)$.

\section{HASIL DAN PEMBAHASAN}

\section{Karakteristik Responden}

Karakteristik responden dalam penelitian ini meliputi jenis kelamin, usia, pekerjaan dan bentuk makanan disajikan pada tabel 1 . Pada tabel 1 menunjukkan jenis kelamin responden terbanyak adalah lakilaki dengan presentase 52,1\%. Responden penelitian ini memiliki jumlah yang hampir sama antara lakilaki dan perempuan. Jenis kelamin dapat mempengaruhi persepsi terhadap kepuasan pelayanan karena perempuan lebih detail dalam melihat penampilan dibandingkan laki-laki. Laki-laki dianggap lebih flexibel sehingga lebih mudah menerima perbedaan (Utami, 2018).

Analisa data menggunakan uji chi-square dengan tingkat kepercayaan sebesar $95 \%(\alpha=0,05)$ Kelompok umur responden rawat inap RSU Haji Surabaya terbanyak adalah lansia awal (46-55 tahun) yaitu sebesar 39,6\%. Berdasarkan buletin Kementerian Kesehatan tentang Gambaran Kesehatan Lanjut Usia di Indonesia menyatakan dengan bertambahnya umur, fungsi fisiologis mengalami penurunan akibat proses degeneratif (penuaan) sehingga meningkatkan resiko penyakit tidak menular pada masa lansia seperti hipertensi, stroke, jantung dan diabetes melitus (Pusat Data dan Informasi Kemenkes RI, 2013).

Pekerjaan responden terbanyak adalah swasta (50\%) yang terdiri dari pedagang, buruh pabrik, karyawan swasta dan penjaga toko. Data dari Profil Kota Surabaya tahun 2017 menyatakan mayoritas warga Surabaya bekerja dalam sektor perdagangan dan jasa seperti pedagang besar atau eceran (Pemerintah Kota Surabaya, 2017). Pekerjaan dapat mempengaruhi kepuasan dalam memberikan penilaian terhadap pelayanan karena seseorang yang bekerja memungkinkan mendapatkan informasi yang lebih luas sehingga mempengaruhi kepuasan dalam pemberian pelayanan jasa dan produk (Utami, 2018).

Jenis makanan yang paling banyak dikonsumsi oleh responden adalah makanan biasa (nasi) dengan presentase 52,1\%. Pemberian diet di rumah sakit disesuaikan dengan kondisi pasien sehingga terbagi antara bentuk makanan biasa dan makanan lunak (Anita, 2016). Kebiasaan makan pasien di rumah dapat mempengaruhi selera sehingga mempengaruhi kepuasan pada pelayanan makan di rumah sakit dan meningkatkan jumlah sisa makanan (Nuraini, Bintanah and Nugraheni, 2011).

Tingkat kepuasan pada pelayanan makan di Rumah Sakit Haji Surabaya menunjukkan 22 menyatakan puas $(45,8 \%)$ dan 26 tidak puas $(54,2 \%)$. Dari wawancara kepada responden didapatkan hasil bahwa alasan ketidakpuasan disebabkan suhu makanan sudah dingin, cita rasa yang hambar karena sakit, berkurangnya nafsu makan, cemas, kesulitan menelan dan menginginkan makanan biasa (nasi). Beberapa pasien mengatakan bahwa makanan sudah bervariasi dengan penampilan yang menarik namun karena berkurangnya selera makan sehingga pasien hanya bisa makan dengan porsi sedikit. Selera makan berpengaruh terhadap kepuasan pelayanan makan di rumah sakit karena dipengaruhi oleh kondisi seseorang yaitu rasa tidak senang, rasa takut karena sakit, ketidakbebasan gerak karena adanya penyakit(Mulyani, 2014). Penelitian Iftiah di Yogyakarta menyatakan ada hubungan signifikan antara kondisi psikologis dengan 
kepuasan pelayanan makanan( $\mathrm{p}=0,002)$ (Iftitah, Sari and Waryana, 2017). Responden dengan kondisi ansietas dan cemas cenderung lebih banyak menyisakan makan dan mempengaruhi tingkat kepuasannya(Iftitah, Sari and Waryana, 2017).

Tabel 1. Distribusi Jenis Kelamin, Umur, Pekerjaan, Bentuk Makanan dan Kepuasan Responden RSU Haji Surabaya Tahun 2018

\begin{tabular}{lcc}
\hline Karakteristik & n & \% \\
\hline Jenis Kelamin & 23 & 47,9 \\
Perempuan & $\mathbf{2 5}$ & $\mathbf{5 2 , 1}$ \\
Laki-laki & 48 & 100 \\
\hline Total & 10 & 20,8 \\
Umur (tahun) & 11 & 22,9 \\
Dewasa Awal (26-35) & $\mathbf{1 9}$ & $\mathbf{3 9 , 6}$ \\
Dewasa Akhir (36-45) & 8 & 16,7 \\
Lansia Awal (46-55) & 48 & 100 \\
Lansia akhir (56-65) & & 22,9 \\
Total & 11 & 27,1 \\
Pekerjaan & 13 & $\mathbf{5 0}$ \\
IRT & $\mathbf{2 4}$ & 100 \\
PNS & 48 & $\mathbf{5 2 , 1}$ \\
Swasta & & 47,9 \\
\hline Total & $\mathbf{2 5}$ & 100 \\
\hline Jenis Makanan & 23 & 45,8 \\
Biasa & 48 & $\mathbf{5 4 , 2}$ \\
\hline Lunak & & 100 \\
\hline Total & 22 & $\mathbf{2 6}$ \\
\hline Pepuasan Pasien & 48 & \\
\hline Tidak Puas & & \\
\hline Total & & \\
\hline
\end{tabular}

\section{Kepuasan Makan Berdasarkan Kualitas dan Pelayanan Makanan}

Hasil pengamatan dan wawancara kepuasan makan pada penyelenggaraan makan dapat dilihat pada Tabel 2 dan 3. Salah satu tolak ukur kesuksesan penyelenggaraan makanan adalah kepuasan makan sehingga keberhasilannya sangat ditentukan dari proses mulai persiapan bahan sampai pendistribusian kepada konsumen(Yuliani, 2007). Tabel 2 menunjukkan hasil survey kepuasan berdasarkan kualitas makanan pada penyelenggaraan makanan. Kualitas makanan dipengaruhi beberapa hal diantaranya adalah besar porsi, variasi menu, penampilan makanan serta warna makanan(Aliffianti, 2016). Pada indikator porsi makanan, sebanyak $91,7 \%$ responden telah puas dengan porsi yang telah disajikan dan hanya $8,3 \%$ yang merasa tidak puas karena merasa porsi makanan terlalu sedikit. Besar porsi dapat mempengaruhi penampilan makanan dan persepsi pasien, makanan dengan porsi terlalu besar atau terlalu sedikit akan mempengaruhi daya terima dan kepuasan pada pasien(Damayanti, 2016).

Indikator cita rasa makanan menunjukkan sebanyak 60,4\% menyatakan puas dan 19 menyatakan tidak puas. Ketidakpuasan ini disebabkan karena responden merasa makanan terasa hambar, makanan sudah dingin, tidak adanya nafsu makanan serta beberapa responden menginginkan makanan biasa. Jenis diet pada pasien biasanya akan mempengaruhi rasa makanan, misalkan pasien dengan diet rendah garam maka makanan yang disajikan akan terasa lebih hambar. Begitupula sebaliknya dengan makanan TKTP atau Tinggi Kalori Tinggi Protein yang cita rasa lauk dan sayur tidak hambar(Moehji, 1992). Selain itu jenis makanan pasien juga disesuaikan dengan penyakit dan kondisi pasien sehingga memungkinkan terjadi gangguan pada panca indera. Penelitian Jessri, dkk mendapatkan hasil bahwa adanya perbedaan pada jenis penyakit akan mempengaruhi daya terima terhadap makanan karena indra perasa yang mengalami gangguan sehingga mempengaruhi penilaian kepuasan makanan(Jessri M, Mirmiran P, Jessri M, Johns N, Rashidkhani B, Amiri P, Barfmal N, 2011). Dari indikator tekstur makanan menunjukkan sebanyak 48 responden merasa puas. Sedangkan indikator warna makanan menunjukkan 87,5\% merasa puas, dan 12,5 merasa tidak puas karena merasa kurang variasi dalam satu sajian makan. 
Tabel 2. Distribusi Hasil Survey Kepuasan Makan Pasien Berdasarkan Kualitas Makanan Pada Penyelenggaraan Makanan di RSU Haji Surabaya

\begin{tabular}{lccccccccc}
\hline Indikator Penilaian & & $\mathbf{1}$ & $\mathbf{2}$ & \multicolumn{3}{c}{$\mathbf{3}$} & $\mathbf{4}$ \\
\cline { 2 - 10 } & $\mathbf{n}$ & $\mathbf{\%}$ & $\mathbf{n}$ & $\mathbf{\%}$ & $\mathbf{n}$ & $\mathbf{\%}$ & $\mathbf{n}$ & $\mathbf{\%}$ \\
\hline Porsi Makanan & 0 & 0 & 4 & 8,3 & 44 & 91,7 & 0 & 0 \\
Rasa Makanan & 0 & 0 & 19 & 39,6 & 29 & 60,4 & 0 & 0 \\
Tekstur Makanan & 0 & 0 & 0 & 0 & 48 & 100,0 & 0 & 0 \\
Warna Makanan & 0 & 0 & 6 & 12,5 & 42 & 87,5 & 0 & 0 \\
\hline
\end{tabular}

Keterangan : 1 : Sangat tidak puas; 2 : Tidak puas; 3 : Puas; 4 : Sangat puas

Tabel 3. Distribusi Hasil Survey Kepuasan Makan Pasien Berdasarkan Kualitas Pelayanan Pada Penyelenggaraan Makanan di RSU Haji Surabaya

\begin{tabular}{|c|c|c|c|c|c|c|c|c|}
\hline \multirow{2}{*}{ Indikator Penilaian } & \multicolumn{2}{|c|}{1} & \multicolumn{2}{|c|}{2} & \multicolumn{2}{|c|}{3} & \multicolumn{2}{|c|}{4} \\
\hline & $\mathbf{n}$ & $\%$ & $\mathbf{n}$ & $\%$ & $\mathbf{n}$ & $\%$ & $\mathbf{n}$ & $\%$ \\
\hline & 0 & 0 & 6 & 12,5 & 42 & 87,5 & 0 & 0 \\
\hline Penyajian Makanan & 1 & 2,1 & 2 & 4,2 & 43 & 89,6 & 2 & 4,2 \\
\hline Alat Makan & 0 & 0 & 3 & 6,3 & 44 & 91,7 & 1 & 2,1 \\
\hline Pembagian Makanan & 0 & 0 & 1 & 2,1 & 47 & 97,9 & 0 & 0 \\
\hline Petugas Penyaji & 0 & 0 & 1 & 2,1 & 44 & 91,7 & 3 & 6,3 \\
\hline Konsultasi Gizi & 0 & 0 & 22 & 45,8 & 26 & 54,2 & 0 & 0 \\
\hline
\end{tabular}

Tingkat Kepuasan

Keterangan : 1 : Sangat tidak puas; 2 : Tidak puas; 3 : Puas; 4 : Sangat puas

Tabel 3 menunjukkan hasil survey kepuasan berdasarkan kualitas pelayanan pada penyelenggaraan makanan. Pada indikator penyajian makanan, terdapat $12,5 \%$ merasa tidak puas dikarenakan makanan yang disajikan kurang menarik. Indikator penggunaan alat makan menunjukkan $89,6 \%$ puas dan ditemukan sebanyak 4,2\% tidak puas karena merasa penggunaan plastik untuk wadah bubur kacang ijo dapat mengubah cita rasa sehingga menginginkan penggunaan gelas atau mangkok. Indikator pembagian makanan menunjukkan sebanyak $91,7 \%$ telah merasa puas terutama dalam jam pembagian makanan. Hanya $2,1 \%$ saja merasa tidak puas dikarenakan berbeda dengan kebiasaan makan saat dirumah. Pada indikator petugas penyaji menunjukkan sebanyak 97,9\% merasa puas karena petugas penyaji telah mengantarkan makanan dengan ramah. Sikap petugas yang ramah merupakan faktor penting untuk meningkatkan kepuasan pelayanan kepada pasien karena petugas penyaji menjadi perantara agar terjalin komunikasi yang baik(Rusdiana Dewi and Adriani, 2017). Indikator konsultasi gizi menunjukkan 91,7\% merasa puas dikarenakan pasien merasa mendapatkan informasi yang bermanfaat untuk kesehatan dirinya maupun keluarganya.

\section{Hubungan Kepuasan Pelayanan Makanan dengan Jenis Diet}

Hasil analisa bivariat pada Tabel 4 menunjukkan bahwa ada hubungan antara kepuasan pelayanan makanan dengan jenis diet $(\mathrm{p}=0,002)$. Responden yang mendapatkan makanan dengan jenis lunak lebih banyak menunjukkan ketidakpuasan terhadap pelayanan gizi. Responden memerlukan konseling lebih lanjut bahwa makanan yang disajikan rumah sakit berguna untuk proses penyembuhan serta mempertahankan daya tahan tubuh sehingga harus memenuhi kualitas, kuantitas, kecukupan gizi ataupun dietnya (Ariyanti, Widyaningsih and Rauf, 2017). Ketidakpuasan dapat disebabkan karena penurunan nafsu makan, aktifitas yang menurun, reaksi obat-obatan serta kondisi mental karena sakit yang sedang dialami (Herlina, 2015).

Tabel 4. Hubungan Kepuasan Pelayanan Makanan dengan Jenis Diet

\begin{tabular}{lcccc}
\hline \multirow{2}{*}{ Jenis Diet } & \multicolumn{2}{c}{ Tingkat Kepuasan } & Total & Chi-square Test \\
\cline { 2 - 3 } & Puas & Tidak Puas & & 22 \\
Lunak & 3 & 19 & 26 & 0,002 \\
Biasa & 15 & 11 & 30 & \\
Total & 18 & 30 & & 30 \\
\hline
\end{tabular}


Makanan lunak diberikan kepada pasien dengan kondisi tertentu seperti pasca bedah, pasien dengan penyakit infeksi, mengalami kenaikan suhu yang tidak terlalu tinggi, pasien yang mengalami kesulitan menelan dan pasien yang sedang mengalami perpindahan dari makanan saring ke makanan biasa (Almatsier, 2001). Penurunan nafsu makan dapat terjadi pada otak ataupun reseptor indera rasa pengecap pada taste buds. Perubahan predominan rasa pahit dapat mengubah cita rasa (Sunariani, 2009). Hasil pengamatan dan wawancara kepada responden menyatakan bahwa citarasa pada makanan lunak dirasa lebih hambar sehingga responden merasa kurang sesuai dan menginginkan makanan biasa (nasi). Pendapat responden ini dikarenakan makanan lunak mempunyai kadar air yang tinggi sehingga volumenya besar dan konsistensi lembek, selain itu makanan lunak tidak dianjurkan menggunakan bumbu yang merangsang (Herlina, 2015). Keadaan inilah yang membuat makanan lunak menjadi hambar dan tidak disukai pasien (Herlina, 2015).

Cara pengolahan makanan lunak di RSU Haji dengan ditim, dibubur, dikukus, direbus, dipanggang atau dibuat puding. Makanan lunak di RSU Haji Surabaya tidak digoreng, menggunakan sayuran dengan kandungan serat lebih rendah seperti buncis muda, labu siam, wortel dan kacang panjang, menggunakan buah-buahan rendah serat dan tidak menimbulkan gas serta menggunakan bumbu dalam jumlah terbatas terutama cabe dan merica. Makanan lunak terbagi menjadi 3 kali makan dan 2 kali selingan. Cara pengolahan ini telah sesuai dengan teori yang menyatakan bahwa makanan lunak harus mempunyai kandungan zat gizi yang cukup, tekstur mudah dikunyah, ditelan dan dicerna, bumbu cukup namun tidak merangsang, cara pengolahan tidak digoreng, dan menggunakan buah dan sayur rendah serat (Almatsier, 2001).

Penelitian Anita tentang faktor yang berhubungan dengan daya terima makanan lunak mendapatkan hasil bahwa sebanyak 55,4\% responden memiliki daya terima kurang baik terhadap makanan lunak yang dipengaruhi oleh faktor penampilan, rasa, menu dan pelayanan penyajian makanan (Anita, 2016). Penelitian Herlina di RS dr M Salamun Bandung menunjukkan dari 26 responden, 19 diantaranya memiliki daya terima kurang baik terhadap makanan lunak $(73,1 \%)$ (Herlina, 2015). Penelitian Farida menyatakan bahwa semakin baik tingkat kepuasan maka semakin sedikit sisa makan pada pasien dengan nilai $p=0,007$. Kepuasan merupakan suatu hasil dari tingkat harapan yang dirasakan (Farida, 2018). Apabila suatu kegiatan melebihi harapan maka seseorang akan merasa puas, sebaliknya apabila jauh dari harapan makan seseorang akan merasa tidak puas (Farida, 2018).

\section{KESIMPULAN}

Dapat disimpulkan bahwa kepuasan pelayanan makan pasien memiliki hubungan dengan jenis diet $(\mathrm{p}=0,002)$. Responden yang mendapatkan makanan dengan jenis lunak lebih banyak menunjukkan ketidakpuasan terhadap pelayanan gizi yang disebabkan karena penurunan nafsu makan, aktifitas yang menurun, reaksi obat-obatan serta kondisi mental karena sakit yang sedang dialami. Bagi instalasi gizi diharapkan melakukan evaluasi secara menyeluruh agar mengetahui penyebab ketidakpuasan pasien sehingga dapat meningkatkan daya terima terhadap makanan lunak maupun makanan biasa. RSU Haji Surabaya telah rutin melaksanakan konseling kepada pasien namun perlu untuk lebih diperjelas lagi bahwa makanan yang disajikan rumah sakit berguna untuk proses penyembuhan serta mempertahankan daya tahan tubuh sehingga harus memenuhi kualitas, kuantitas, kecukupan gizi ataupun diet yang sesuai dengan penyakitnya.

\section{ACKNOWLEDGEMENT}

Penulis mengucapkan terima kasih kepada seluruh staf pengajar Fakultas Kesehatan Masyarakat Universitas Airlangga, pihak Instalasi Gizi di RSU Haji Surabaya atas bimbingan dan bantuan selama pelaksanaan penelitian ini dan para pasien yang telah bersedia menjadi responden.

\section{DAFTAR PUSTAKA}

Aliffianti, R. (2016) Tingkat Kepuasan Pasien Pada Pelayanan Makanan Di Rumah Sakit 'Aisyiyah Purworejo. Universitas Negeri Yogyakarta.

Almatsier, S. (2001) Prinsip Dasar Ilmu Gizi.

Anita, Y. A. (2016) Faktor-Faktor Yang Berhubungan Dengan Daya Terima Makanan Lunak Pasien Rawat Inap Penyakit Dalam Rsud Pasaman Barat Kabupaten Pasaman Barat Tahun 2016. Universitas Andalas. Anwar, I., Herianandita, E. And Ruslita, I. (2012) 'Evaluasi Sistem Penyelenggaraan Makanan Lunak Dan Analisis Sisa Makanan Lunak Di Beberapa Rumah Sakit Di Dki Jakarta', Gizi Indonesia, 35(2), Pp. 97-

108.

Ariyanti, V., Widyaningsih, E. N. And Rauf, R. (2017) 'Hubungan Antara Karakteristik Sensorik Makanan Dengan Sisa Makanan Biasa Pada Pasien Rawat Inap Rsud Dr. Soeratno, Gemolong, 
Kabupaten Sragen', Jurnal Kesehatan, 10(1), Pp. 17-25.

Damayanti, S. (2016) Hubungan Variasi Menu, Besar Porsi, Sisa Makanan Dan Tingkat Kepuasan Pasien Pada Makanan Lunak Di Rumah Sakit Umum Daerah Cengkareng. Universitas Esa Unggul.

Daniella Geertruida Maria Rumokoy*, Nova H. Kapantow*, G. D. K. (2016) 'Faktor-Faktor Yang Berhubungan Dengan Sisa Makanan Pada Pasien Di Kelas Iii Penyakit Dalam Rsup Prof. Dr. R.D. Kandou Kota Manado', Pp. 87-102.

Farida (2018) Hubungan Antara Kualitas Pelayanan Makanan Dan Tingkat Kepuasan Dengan Sisa Makanan Pasien Diabetes Mellitus Tipe Ii Rawat Inap Di Rsi Nu Demak. Universitas Muhammadiyah Surakarta.

Habiba, R. A. And Adriani, M. (2017) 'Hubungan Depresi , Asupan , Dan Penampilan Makanan Dengan Sisa Makan Pagi Pasien Rawat Inap ( Studi Di Rumah Sakit Islam Jemursari Surabaya ) Association Between Depression, Intake, And Appearance Of Food With The Morning Food Waste Among Inpatients ( Study At The Islam Hospital Jemursari Surabaya )', Pp. 198-208. Doi: 10.20473/Amnt.V1.I3.2017.198-208.

Hartwell, H. J. Et Al. (2006) 'Foodservice In Hospital: Development Of A Theoretical Model For Patient Experience And Satisfaction Using One Hospital In The Uk National Health Service As A Case Study *', Journal Of Foodservice, Xvii, Pp. 226-238.

Herlina, F. F. (2015) Hubungan Faktor Eksternal Dan Daya Terima Makanan Lunak Pada Pasien Dewasa Di Rumah Sakit Tni Au Dr. M Salamun Bandung 2015. Politeknik Kesehatan Kemenkes Bandung.

Hospitality, N. (2005) 'Managing Food Waste In The Nhs'. Uk: Departement Of Health, Nhs Estates.

Iftitah, F., Sari, T. And Waryana (2017) Hubungan Kondisi Psikologis Dan Penampilan Makanan Dengan Sisa Makanan Pasien Rawat Inap Di Rsud Panembahan Senopati Bantul. Politeknik Kesehatan Kementerian Kesehatan Yogyakarta.

Jessri M, Mirmiran P, Jessri M, Johns N, Rashidkhani B, Amiri P, Barfmal N, A. F. (2011) 'A Qualitative Difference. Patients' Views Of Hospital Food Service In Iran', Ncbi, 57(2).

Kementerian Kesehatan Ri (2013) 'Pedoman Pelayanan Gizi Rumah Sakit'. Indonesia.

Marhaeni, D. Et Al. (2014) 'Analisis Pelayanan Gizi Rumah Sakit Dengan Pendekatan Health Technology Assessement ( Hta ) Health Technology Assessment Approach', 1(38), Pp. 97-105.

Mas'ud, H., Nur Rochimiwati, S. And Sahariah Rowa, S. (2015) 'Studi Evaluasi Sisa Makanan Pasien Dan Biaya Makanan Pasien Di Rsk Dr Tadjuddin Chalid Dan Rsud Kota Makassar', Media Gizi Pangan, Xix(Sisa Makanan Pasien, Biaya Makanan Pasien), Pp. 91-95.

Moehji, S. (1992) Penyelenggaraan Makanan Institusi Dan Jasa Boga. Jakarta: Gramedia Pustaka Utama. Mulyani, R. (2014) 'Hubungan Karakteristik Pasien Dengan Kepuasan Pelayanan Gizi Di Ruang Rawat Inap

Rumah Sakit', X(2), Pp. 231-240.

Nuraini, N., Bintanah, S. And Nugraheni, K. (2011) 'Suhu Makanan Dan Sisa Makanan Pasien Dewasa Diet Lunak Di Rawat Inap Penyakit Dalam Rumah Sakit Umum Daerah Kota Semarang’, Pp. 41-49.

Oktaria (2014) Hubungan Kepuasan Pelayanan Gizi Dengan Sisa Makanan Pasien Di Rumah Sakit Bhayangkara Kediri, Skripsi Yang Tidak Terpublikasi. Universitas Brawijaya, Malang.

Pemerintah Kota Surabaya (2017) 'Statistik Sektoral Kota Surabaya Tahun 2017 : Penduduk Dan Tenaga Kerja'. Surabaya: Pemkot Surabaya.

Pusat Data Dan Informasi Kemenkes Ri (2013) 'Gambaran Kesehatan Lanjut Usia Di Indonesia', Kementerian Kesehatan Ri.

Rusdiana Dewi, S. And Adriani, M. (2017) 'Perbedaan Kepuasaan Pasien Terhadap Makanan Dengan Sistem Penyelenggaraan Outsourcing Dan Swakelola Di Rs Islam Jemursari Surabaya Difference Patient Satisfaction Of Food By Outsourcing And Self Operated Foodservice System In Rs Islam Jemursari Surabaya', Pp. 209-219. Doi: 10.20473/Amnt.V1.I3.2017.209-219.

Sugiyono (2009) Metode Penelitian Kuantitatif, Kualitatif Dan R\&D. Bandung: Alfabeta.

Sunariani, J. (2009) 'Perubahan Konsentrasi Il-1 Dan Gustducin Terhadap Rasa Pengecap Pahit Pada Demam', J. Penelit. Med. Eksakta, 8(3), Pp. 159-167.

Utami, Y. T. (2018) 'Pengaruh Karakteristik Pasien Terhadap Kualitas Pelayanan Rawat Jalan Di Uptd Puskesmas Penumping Surakarta', 8(1), Pp. 57-65.

Yuliani, D. (2007) Penilaian Mutu Makanan Pada Sistem Penyelenggaraan Makanan Yang Berbeda Di Rumah Sakit Umum Dr. Zainoel Abidin Dan Di Rumah Sakit Kesdam Banda Aceh. Universitas Gajah Mada, 2007. 